\title{
Kullanılan Farklı Katkı Maddelerinin ve Farklı Beton Dayanım Seviyelerinin Kısa Kirişlerin Sünekliğine Etkisi
}

\author{
Atila KUMBASAROGLU ${ }^{1 *}$, Halil İbrahim SEZGINº
}

${ }^{1}$ Erzincan Binali Yıldırım Üniversitesi Mühendislik Fakültesi, İnşaat Mühendisliği Bölümü, Erzincan, Türkiye

${ }^{2}$ Erzincan Binali Yıldırım Üniversitesi Mühendislik Fakültesi, İnşaat Mühendisliği Bölümü, Erzincan, Türkiye

Geliş / Received: 04/04/2020, Kabul / Accepted: 30/05/2020

\begin{abstract}
$\ddot{\mathbf{O z}}$
Kısa açıklıklı kirişler, genellikle yüklerin aktarılması sırasında oluşan aşırı kesme kuvvetleri nedeniyle süneklik sorunlarına neden olan yetersiz eğilme kapasitelerine sahiptir. Etriyelerin kullanımına ek olarak enine donatı demirlerinin kısmen veya tamamen yerini alması için kullanılan alternatif katkı maddeleri son zamanlarda tamamen betonarme elemanların kesme kapasitelerinin arttırılmasına odaklanmıştır. Bu çalışmada kısa açıklıklı kirişlerin farklı katkı maddelerine sahip olarak farklı beton dayanım seviyelerinde eğilme kapasitelerinin arttırılmasının araştırılması için deneysel bir çalışma yapılmıştır. Toplam 14 adet deneysel betonarme kısa-açıklıklı kiriş numuneleri, üç noktadan eksenel eğilme testine tabi tutulmuştur. Her bir deneysel numune için göçme modelleri sunulmuştur. Her biri farklı tasarlanmış kısa açıklıklı kirişlerin yük yer değiştirme ilişkileri, başlangıç rijitliği, süneklik oranları ve enerji yutma kapasiteleri değerlendirilmiştir. Sonuç olarak, daha güçlü aderans özelliğine sahip olan katkı malzemesi ile daha yüksek bir eğilme kapasitesi sağlanmış ve böylece kısa açıklıklı kirişlerde daha sünek bir davranış elde edilmiştir.
\end{abstract}

Anahtar Kelimeler: Kısa-açıklıklı kirişler, süneklik oranı, başlangıç rijitliği, enerji yutma kapasitesi.

\section{The Effect of Different Additives Materials and Different Concrete Strength Levels on the Ductility of Short Beams}

\begin{abstract}
Short-spanned beams generally have inadequate flexural capacities to transfer the loads which cause ductility problems due to over exceeded shear forces. In addition to the use of stirrup alternative additive materials which are used for partially or fully replacing the stirrup bars have recently been met focus entirely on increasing the shear capacities of reinforced concrete members. In this study, an experimental study was conducted to investigate the improving of flexural capacity of short-spanned beams at different used concrete strength levels with different admixtures. A total of fourteen experimental reinforced concrete beams were tested under three point flexural strength tests. Failure patterns for each specimen were presented. Loaddisplacement relationships, initial stiffness, ductility ratio and energy dissipation capacities of different designed short-spanned beams were evaluated. As a result, the admixture material, which has a stronger adhesion property, was provided a higher bending capacity and thus a more ductile behaviour was achieved in the short-spanned beams.
\end{abstract}

Keywords: Short-spanned beams, ductility ratio, initial stiffness, energy dissipation capacity. 


\section{Giriş}

Yapisal nedenlerle ve mimari gereksinimlerle yapıda kaçınılmaz olan kısa açıklıklı kirişler, yüksek kesme davranışları nedeniyle yapının sergilediği süneklik üzerinde sınırlayıcı bir faktör olabilmektedir. Kısa açıklıklı kirişler, özellikle sismik yükler söz konusu olduğunda betonarme kirişlerin kayma dayanımı ve rijitliğinde hızlı bir şekilde bozulmaya yol açan kayma deformasyonlarının büyük bir tersinen ve tekrarlanan çevrimlerine maruz kalabilir (Wight ve Macgregor, 2012; Lele ve Maiti, 2002; Campione ve Mangiavilla-no, 2008; Karami, Malekzadeh, ve Shahpa-ri, 2003; Khan, Smith ve Izzuddin, 2013). Kesme modunun daha gevrek olması ve ani olarak göçme modu sergilediğinden, özellikle kısa açıklıklı kirişlerin kesme kapasitesinin, sünek tasarım ile elde edilmesi için sismik yükler altında tasarımı yapılan yapıların eğilme kapasitesinden daha yüksek olmalıdır (Campione ve Mangiavilla-no, 2008; Caglar, Demir, Ozturk ve Akkaya, 2015). Kisa açıklıklı kirişlerin daha yüksek bir kesme kapasitesi ile tasarlanması, betonarme kirişlerde oluşabilecek kesme çatlaklarının bir a ̆ şeklinde çoklu çatlaklar oluşturup yayılması ile ani göçme modunun oluşmasını önleyebilir (Yazdanbakhsh, Altoubat ve Rieder, 2015).

$\mathrm{Bu}$ konu kapsamında yürütülen çalışmalardan birisi, on iki adet kısa açıklıklı, düzlemiçi ve lifli betonarme kirişlerin eğilme davranışını monotonik ve tersinir tekrarlanır yükler altında analiz etmek için Campione ve Mangiavillano (2008) tarafından yapılmıştır. Gerçekleştirilen çalışmada, kısa açıklıklı kirişlerin sismik yükler altında büyük tersinir kayma deformasyonlarına maruz kalabileceği gösterilmiştir. Ayrıca bu çalışmadaki test sonuçlarından liflerin eklenmesinin kirişlerin taşıma kapasitesini arttırdığını ve daha fazla sünek davranış sağladığını ve aynı zamanda sismik yükler altında göçme modu etkilerini de azalttığını göstermiştir. Yazdanbakhsh, Altoubat ve Rieder (2015) tarafından betonarme kirişlerin boyuna doğrultudaki kesme kapasitesinin ölçülmesi ve modellenmesi için parametrik bir araştırma yapılmıştır. $\mathrm{Bu}$ çalışmada, test edilen 23 adet büyük ölçekli narin ve kısa açıklıklı betonarme kirişlerden elde edilen sonuçlar sunulmuş ve deneysel değişkenler, kesme açıklığı-derinlik oranı, lif hacim oranı, eğilme donatı çubuk oranı ve kiriş derinliğini içermektedir. Tüm kirişler beklenti doğrultusunda kesme modunun gerçekleşmesi için yer değiştirme kontrollü olmak üzere üç noktadan eksenel eğilme yüklemesi altında test edilmiştir. Yapılan çalışmanın sonucunda test verileri, önerilen modellerin öngördüğü teorik değerlerle karşılaştırılmıştır ve önerilen modelin iyimser olarak haklılığı savunul-muştur.

Konvansiyonel tasarımda, enine etriye donatı çubuklarının sıklaştırılmasının veya literatürde kabul görmüş mevcut kodlarda verilen etriye donatısı aralıklarının azaltılmasının, taşıyıcı betonarme elemanların kayma gerilmelerine dayanımında yeterli çözüm olmayacağı yazarların bilgisi dahilinde bilinmektedir (Demir, Caglar, Ozturk ve Sumer, 2016; Kuo, Cheng ve Hwang, 2010; Yu ve Bažant, 2011; Syroka-Korol ve Tejchman, 2014). Ayrıca ACI 318-14 (2011) gibi birçok tasarım kodunda alternatif kesme donatısı olarak kullanılabileceği önerilen eğimli etriye demirleri ve/veya pilye donatı çubukları yalnızca boyuna doğrultuda yerleştirilebildiği gerekçesiyle, kısa açıklı kirişler için, kesme taleplerini telafi edememektedir (Wight ve Macgregor, 2012; Demir, Caglar, Ozturk ve Sumer, 2016). Ayrica yapısal gereksinimler nedeniyle özellikle bağlantı bölgelerinde bulunabilen kısa açıklıklı kirişlerde, kesme mukavemetinin artırılması için uygulamada 
kabul görmüş olan diyagonal doğrultulu enine etriye donatısı yerleştirilmesi yöntemi de, enine donatı çubuklarının büyük eğimle yerleştirilmesi gerekliliği nedeniyle en boy oranı $\left[\ell_{n} / h<4\right.$, burada $\ell_{n}$ kirişin net uzunluğu ve $h$ kiriş derinliğidir] açısından çok etkili görülmemektedir (Demir, Caglar, Ozturk ve Sumer, 2016; ACI 318-14 (2011).

Aynı zamanda, Demir, Caglar, Ozturk ve Sumer (2016) tarafindan, betonarme T-kesitli kirişlerde kayma kapasitesinin, alternatif diyagonal bir kayma donatısı vasıtasıyla artırılması için analitik bir araştırma da yapılmıştır. Yürütülen çalışmada, monotonik ve tersinen-tekrarlanan yüklemeler altında betonarme kirişlerin kayma kapasitesinin ve sünekliğinin artırılabilmesi için kolay uygulanabilir, ekonomik ve alternatif bir teknik olarak diyagonal kayma donatısı (DSR) adı verilen yeni bir donatı konfigürasyonu önerilmiştir. Çalışma kapsamında elde edilen sayısal sonuçlar, önerilen diyagonal kayma donatısının (DSR) dâhil edildiğinde betonarme kirişlerin kesme ve süneklik kapasitesinde önemli bir artış olduğunu göstermiştir. Ayrıca, diyagonal kayma donatısının (DSR) çapındaki ve akma mukavemetindeki bir artışla, kesme kapasitesinin daha da arttığ 1 ve göçme mekanizmasının kesme modundan eğilme moduna geçebildiği de gösterilmiştir. Diğer bir analitik araştırma Kuo, Cheng ve Hwang (2010) tarafindan, betonarme kirişlerin yük taşıma mekanizmasını ve kayma mukavemetini araştırmak için yapılmıştır. Betonarme kirişlerdeki kayma kuvvetlerinin aktarım mekanizmasının, kiriş bölgelerinde iletilen yük güzergâhlarına göre karakterize edilebileceği ileri sürülmüştür. Bir başka parametrik araştırma ise Yu ve Bažant (2011) tarafindan, betonarme kirişlerin kesme donatılarının (etriyelerin) kayma (kesme) mukavemeti üzerindeki boyut etkisini göstermek için yapılmıştır. Elde edilen veriler çatlama mekaniğine göre sonlu elemanlar analizine dayanan tam-ölçekli kiriş testleri ile kalibre edilmiştir. Bu çalışmada, yeniden bir araya getirilmiş 234 adet test veri tabanının istatistiksel analizle homojen olmamalarından kaynaklanan yanıltıcı boyut etkilerini ortadan kaldırmak amacıyla ikincil etki parametreleri filtrelenmiştir. Sonuç olarak her iki yaklaşım da kesme donatılarının boyutsal etkiyi tamamen baskılayamadığını göstermiştir. Bir başka deneysel çalışma ise Syroka-Korol ve Tejchman (2014) tarafından, boyuna doğrultuda donatılı ve kesme donatı çubukları olmayan beton kirişler için yapılmıştır. Deneysel yürütülen çalışmadan, kısa kirişlerde nominal kayma mukavemeti üzerindeki boyut etkisinin azımsanmayacak derecede güçlü olduğu sonucuna varılmıştır.

Son dönemlerde betonarme kirişlerde, kesme donatısı çubuklarının kısmen veya tamamen yerini alabilen ve/veya korozyona uğramayan farklı katk1 maddelerinin kullanımı ile kesme kapasitesinin artırılması için yöntemler geliştirilmektedir (Yalciner, Kumbasaroglu ve Ergun, 2018; Bicer, Yalciner, Balk1s, ve Kumbasaroglu, 2018; Kumbasaroglu ve Korkmaz, 2020). Özellikle Yalciner, Balkıs, ve Kumbasaroglu (2018) tarafından, kesme donatılarının yerine farklı kullanılan plastik elyaf miktarlarının geo-grid ile kullanılabilirliğini incelemek için yapılan çalışma benzersizdir. Çalışmadan elde edilen test sonuçları, betonarme kirişlerin aderans mukavemetini ve kesme kapasitesini etriye donatı çubukları olmaksızın geri kazanması için daha fazla miktarda plastik elyaf kullanıldığını göstermektedir. Bu çalışmalardaki gibi farklı katkı maddelerinin (örneğin, plastik ve çelik fiberler, geogrid malzemeler, ..., gibi) ilave edildiği tam ölçekli betonarme kirişlerin beton ve/veya eğilme-kesme mukavemetine ait mekanik özellikleri geniş çapta araştırılmış olsa da, farklı katk1 maddelerinin ilave 
edildiği kısa açıklıklı betonarme kirişler için yapılan araştırmaların sayısı daha azdır. $\mathrm{Bu}$ nedenle, bu çalışmada farklı kullanılmış katkı maddelerinin (örneğin, poli-propilen fiber, cam elyaflar, paket lastikler, çelik/beton fiberler, ..., gibi) kısa açıklıklı kirişlerin kesme kapasitesi üzerindeki performansını incelemek amacıyla bir dizi deneysel çalışma yapılmıştır.

\section{Materyal ve Metot \\ 2.1. Deneysel numunelerin boyutları}

$\mathrm{Bu}$ çalışmada farklı katkı maddelerine sahip olarak farklı beton basınç dayanım seviyelerinde, eğilme kapasitelerinin arttırılmasının araştırılması amacıyla 14 (on dört) adet kısa açıklıklı betonarme kiriş numuneleri 3 (üç) noktadan eksenel eğilme testine tabi tutulmuştur. Araştırma kapsamında ilave edilen katkı maddelerinin yapısal davranışa olan etkisinin/katkısının daha sağlıklı bir şekilde tartışlabilmesi için tüm betonarme kiriş numunelerinin kesit özellikleri benzer olarak üretilmiştir. Her bir betonarme kiriş numunesinin uzunluğu $900 \mathrm{~mm}$ olup, en-kesit boyutları ise sirasiyla 250 ve $300 \mathrm{~mm}$ 'dir. Her bir betonarme kiriş numunesi farklı konfigürasyonuna sahip olarak tasarlanmıştır. Tüm betonarme kiriş numuneleri için TS708 (2010) şartnamesine uygun olarak donatı kanca uçları önceden hazırlanmış olan çelik donatı çubukları kullanılmıştır. Ayrıca her bir betonarme kiriş numunesinde boyuna doğrultuda eğilme donatı çubuğu olarak 2 (iki) adet $12 \mathrm{~mm}$ çapında donatı çubuğu kullanılmıştır. Çalışma kapsamında yalnızca kullanılan basınç ve askı donatı çubukları test edilen kirişler için farklılık göstermiştir. Deneysel numunelerin donatı çubukları konfigürasyonlarına ait kesit özelliklerinin detayları Tablo 1 'de gösterilmektedir. Tablo 1'de görüldüğü üzere, betonarme kiriş numuneleri, kullanılan farklı ilave katkı maddeleri için farklı etriye (enine donatı çubukları) aralıklarına sahip olarak tasarlanmıştır. $B_{1}$ ile $B_{7}$ olarak adlandırılan betonarme kiriş numuneleri için hiçbir katk1 maddesi kullanılmamıştır. $\mathrm{B}_{7}$ ile $\mathrm{B}_{14}$ olarak adlandırılan betonarme kiriş numuneleri için ise farklı tipte katkı maddeleri (örneğin; poli-propilen fiber, cam fiber, paket lastik, çelik fiber, beton fiber, XPS köpük ve sentetik geogrid) kullanılmıştır.

Betonarme kiriş numuneleri TS 500 (2002) şartnamesine uygun C30 betonu kullanılarak katkısız ve katkılı olmak üzere, laboratuvar şartlarında üretilmiştir. Tüm deneysel kiriş numuneleri için 3 (üç) adet küp numuneler ayrıca alınmıştır ve tüm kiriş numuneler aynı şartlara sahip olarak kür edilmiştir. Kür işlemi sürecinde temin edilen küp numunelerin 28 (yirmi sekiz) günlük beton karakteristik basınç dayanımları ASTM C 39-01 (2001) standardına uygun olarak beton basınç testleri yapılarak elde edilmiştir. Kübik testlerden elde edilen beton karakteristik basınç dayanım seviyeleri Tablo 1'de ayrıca verilmiştir. Betonun basınç dayanım seviyeleri her bir betonarme kiriş numunesinde 21.13 ile 39.83 $\mathrm{MPa}$ arasında değişen farklılıklara sahiptir. Donatı çubukları için yapılan donatı çekme testleri ile malzeme mekanik özelliklerini sağlıklı bir şekilde yansıtan gerilme-birim şekil değiştirme ilişkileri elde edilmiştir. Elde edilen ilişkiye göre $12 \mathrm{~mm}$ çapındaki boyuna eğilme donatı çubuklarının akma ve kopma dayanımları sirasıyla 452 ve $580 \mathrm{MPa}$ olarak ve akma ve kopma dayanımlarına karşı1ık gelen birim şekil değiştirmeler ise sırasıyla 0.0022 ve $0.0108 \mathrm{~mm} / \mathrm{mm}$ olarak elde edilmiştir. Buna karşılık $8 \mathrm{~mm}$ çapındaki enine (etriye) donatı çubuklarının akma ve kopma dayanımları sirasıyla 510 ve $610 \mathrm{MPa}$ olarak ve akma ve kopma dayanımlarına karş1lık gelen birim şekil değiştirmeler ise sirasiyla 0.0026 ve $0.0355 \mathrm{~mm} / \mathrm{mm}$ olarak elde edilmiştir. 
Tablo 1. Deneysel numunelerin donatı çubukları konfigürasyonlarına ait kesit özellikleri.

\begin{tabular}{|c|c|c|c|c|c|c|c|c|c|}
\hline 异 & Betonarme kiriş detayı & $\begin{array}{c}\text { Katkı } \\
\text { maddesi }\end{array}$ & $\begin{array}{c}\rho_{\mathrm{h}} \\
(\mathbf{m m} / \mathbf{m m})\end{array}$ & $\begin{array}{c}\rho_{\mathrm{t}} \\
(\mathbf{m m} / \mathbf{m m})\end{array}$ & $\begin{array}{c}\rho_{\mathrm{c}} \\
(\mathbf{m m} / \mathbf{m m})\end{array}$ & $\underset{(\mathbf{m m})}{\mathbf{S}}$ & $\begin{array}{c}\mathbf{f}_{\mathrm{c}} \\
(\mathbf{M P a})\end{array}$ & $\begin{array}{c}\text { Katkı } \\
\text { maddesi } \\
\text { miktarı } \\
(\mathrm{g})\end{array}$ & $\begin{array}{c}\begin{array}{c}\text { İlave } \\
\text { etriye }\end{array} \\
\text { malzemesi } \\
\left(\mathbf{m}^{2}\right)\end{array}$ \\
\hline $\mathrm{B}_{1}$ & & $\mathrm{x}$ & $\mathrm{x}$ & 0.0033 & 0.0033 & $\varnothing 8 / 400$ & 28.13 & $\mathrm{x}$ & $\mathrm{x}$ \\
\hline $\mathrm{B}_{2}$ & & $\mathrm{x}$ & 0.0033 & 0.0033 & 0.0015 & $\varnothing 8 / 230$ & 24.47 & $\mathrm{x}$ & $\mathrm{x}$ \\
\hline $\mathrm{B}_{3}$ & & $\mathrm{x}$ & 0.0033 & 0.0033 & 0.0033 & $\varnothing 8 / 200$ & 36.10 & $\mathrm{x}$ & $\mathrm{x}$ \\
\hline $\mathrm{B}_{5}$ & & $\mathrm{x}$ & $\mathrm{x}$ & 0.0033 & 0.0033 & $\varnothing 8 / 130$ & 34.33 & $\mathrm{x}$ & $\mathrm{x}$ \\
\hline $\mathrm{B}_{6}$ & & $\mathrm{x}$ & $\mathrm{x}$ & 0.0035 & 0.0035 & $\varnothing 8 / 220$ & 35.80 & $\mathrm{x}$ & $\mathrm{x}$ \\
\hline $\mathrm{B}_{7}$ & 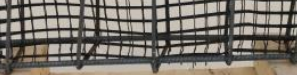 & $\mathrm{x}$ & $\mathrm{x}$ & 0.0035 & 0.0035 & $\varnothing 8 / 150$ & 22.40 & $\mathrm{x}$ & $\begin{array}{c}\text { Geo-grid } \\
0.45\end{array}$ \\
\hline
\end{tabular}


$\mathrm{B}_{8}$

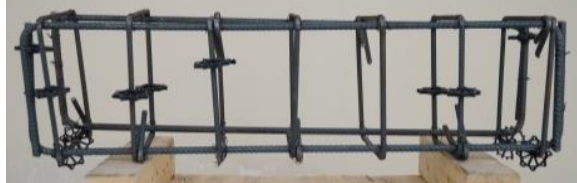

Poli-

0.0033

0.0033

Ø8/130

24.30

630

\section{Cam}

fiber

$\mathrm{x}$

0.0033

0.0033

$\varnothing 8 / 100$

23.73

$470 \quad \mathrm{x}$

$\mathrm{B}_{9}$

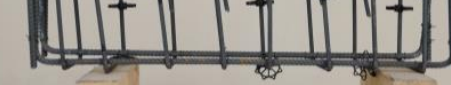

Paket

lastik

0.0033

0.0015

$\varnothing 8 / 150 / 220$

33.70

$1500 \quad \mathrm{x}$

$\mathrm{B}_{11}$

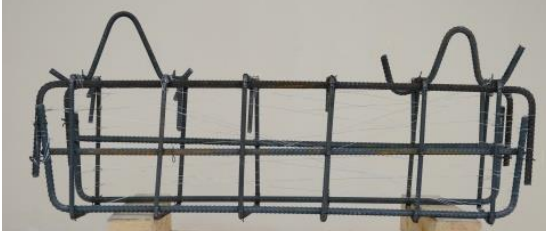

Çelik

fiber

0.0033

0.0033

0.0033

$\varnothing 8 / 150$

26.40

850

$\begin{array}{cccccccc}\begin{array}{c}\text { Beton } \\ \text { fiber }\end{array} & \mathrm{x} & 0.0035 & 0.0035 & \varnothing 8 / 150 & 21.13 & 1800 & \mathrm{x}\end{array}$

$\mathrm{B}_{12}$

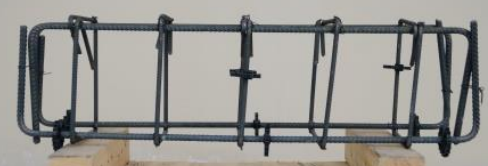

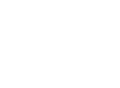
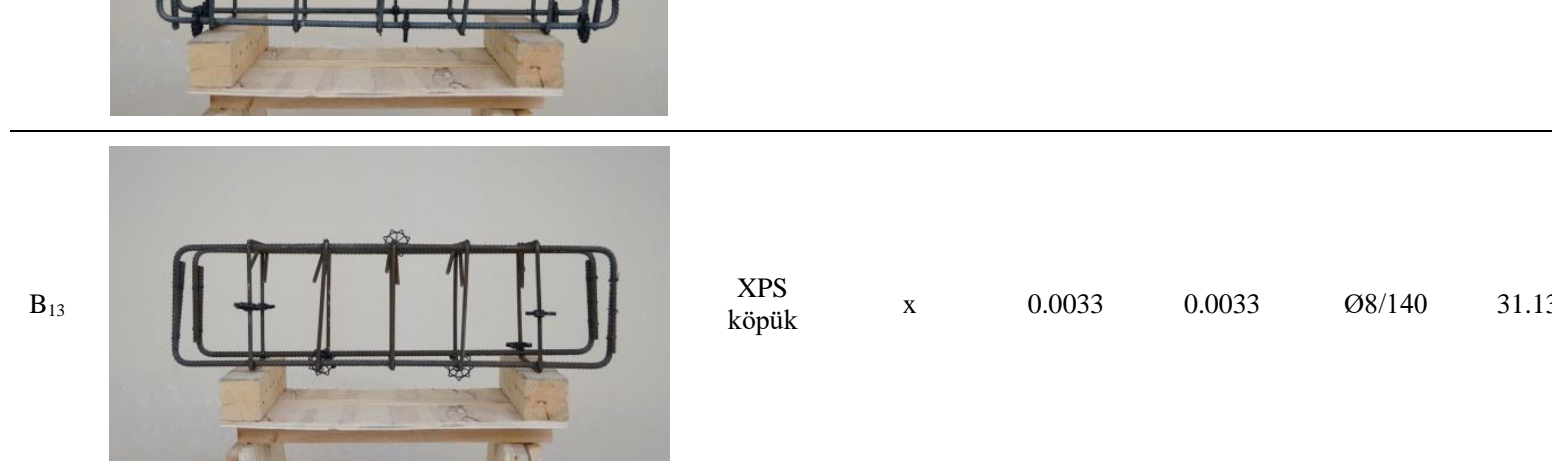

$\begin{array}{cccccccc}\text { XPS } & x & 0.0033 & 0.0033 & \varnothing 8 / 140 & 31.13 & 250 & \text { x } \\ \text { köpük } & \text { x } & & & & \end{array}$

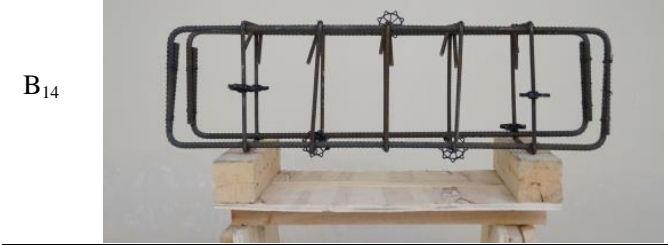

\section{Sentetik} geogrid

$\rho_{\mathrm{h}}$ : Askı çubuklarının donatı oranı, $\rho_{\mathrm{t}}$ : Çekme çubuklarının donatı oranı, $\rho_{\mathrm{c}}$ : Basınç çubuklarının donatı oranı, S: etriye aralığı. 


\subsection{Deneysel kurulum}

Çalışmanın amacı doğrultusunda tasarlanan deneysel kurulum Şekil 1'de şematik olarak gösterilmiştir. Yükleme, betonarme kiriş numunesinin üst yüzeyinin ortasında tek bir noktadan olmak üzere eksenel eğilme yükü (monotonik) olarak uygulanmıştır. Böylece numunelerin mesnetleri de dâhil olmak üzere, yükleme 3 (üç) noktadan yapılarak, tüm numunelerde çekme ve eğilme çatlaklarının oluşması sağlanmıştır.

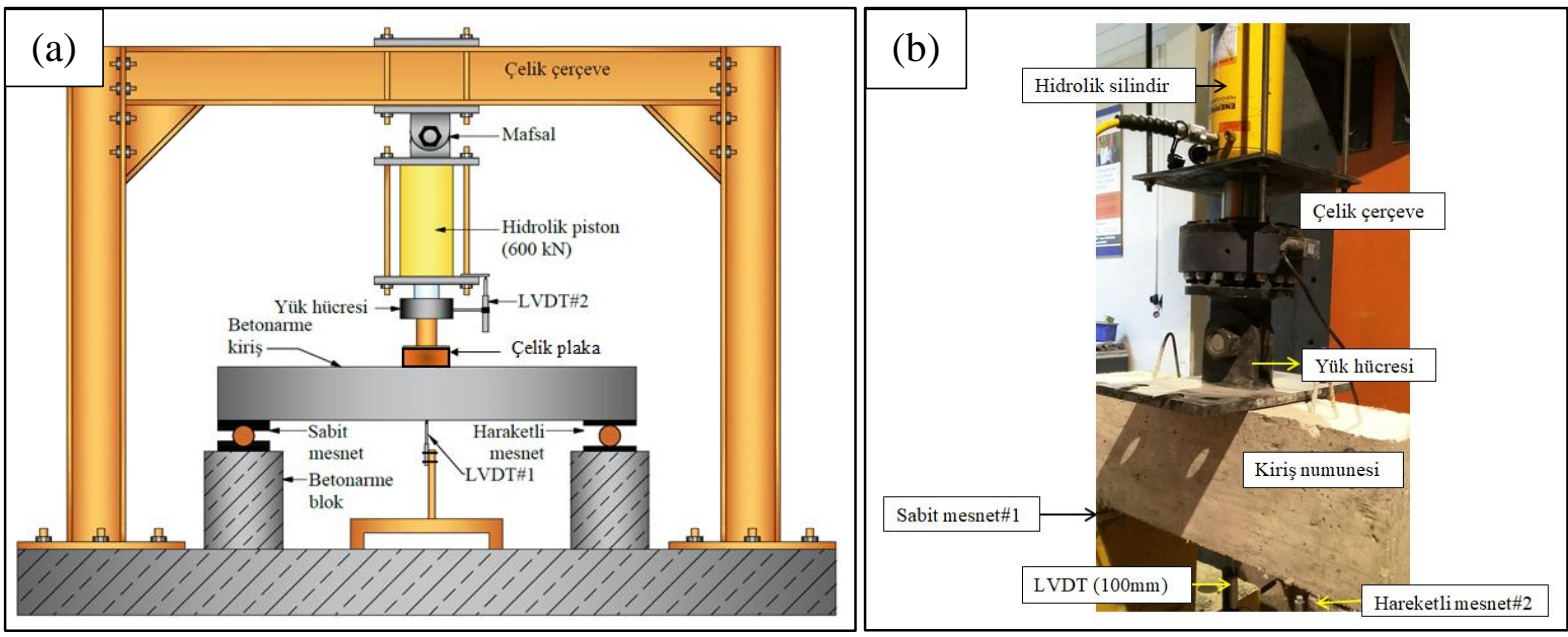

Şekil 1. Deneysel kurulum: (a) şematik gösterimi; (b) perspektif görünüm.

Betonarme taşıyıcı kiriş numunelerinin yapısal davranışlarının sağlıklı bir şekilde yansıtılabilmesi açısından, yük-deplasman ilişkilerinin ölçülebilmesi için, betonarme kiriş numunelerinin merkezi (orta noktası) alt yüzeyine, yükleme doğrultusu ile aynı hizada olacak şekilde, 1 (bir) adet 100 mm'lik doğrusal değişken yer değiştirme ölçer (LVDT) yerleştirilmiştir. Deplasman miktarının, basit mesnetlerin olası yanal hareketinden dolayı hassasiyetinin doğrulanabilmesi için yük hücresi ile hidrolik silindir arasına da ayrıca 1 (bir) adet 200 mm'lik doğrusal değişken yer değiştirme ölçer (LVDT) yerleştirilmiştir. Tek bir noktadan yapılan eksenel basınç (monotonik yükleme) testlerinde 1 (bir) adet 60 ton $(600 \mathrm{kN})$ kapasiteli hidrolik silindir ile hidrolik silindirin ön yüzeyine vidalı 1 (bir) adet 60 ton $(600 \mathrm{kN})$ kapasiteli yükleme hücresi kullanılmıştır. Eksenel eğilme yüküne maruz betonarme kiriş numunelerinin eğilme davranışı sırasında hareketli mesnetin yatay doğrultuda yer değiştirme hareketine karşılık yükün numune yüzeyine her zaman $90^{\circ}$ olarak etki ettirilebilmesi amacıyla çelik çerçeve ile hidrolik silindir arası mafsallı olarak inşa edilmiştir.

Geliştirilen deneysel tasarım kapsamında betonarme kiriş numunelerindeki boyuna ve enine donatı çubukları ile ilave katkı maddeleri, elde edilen farklı talep yüklerinin daha sağlıklı bir şekilde tartışılabilmesi amacıyla değişen boyut/adet ve miktarlarda uygulanmıştır. Monotonik yükleme sistemi ile eş-zamanlı ölçülen yük-deplasman ilişkisine bağlı olarak, elastik veya elastik ötesi davranışlar ve göçme modları, yük taşıma kapasitesi parametresine, kullanılan katkı maddesi türüne, askı/çekme ve basınç donatı oranına ve karakteristik beton basınç dayanım özelliklerine bağlı olarak tartışılmıştır. Böylece geliştirilen deneysel tasarım kapsamında her bir deneysel numune için değişen şartların yapısal davra- 
nışına olan etkisinin daha sağlıklı bir şekilde tahmin edilmesi sağlanmıştır. Deneysel kurulum için betonarme kiriş numunelerine yerleştirilen tüm ölçüm cihazları bir veri toplama sistemi (data-acquisition system) ile eş-zamanlı olarak ölçülerek bilgisayara kaydedilmiştir.

\section{Bulgular}

Çalışma kapsamında kullanılan farklı katkı maddelerinin, uygulanan farklı etriye araliklarının, tasarlanan farklı oranlarda ask1, çekme ve basınç donatısı oranlarının ve yapılan basınç testleri sonucu elde edilen farklı karakteristik beton basınç dayanımlarının, taşıyıcı betonarme kısa açıklıklı kirişlerin süneklik düzeylerine ve göçme modlarına olan etkilerinin daha sağlıklı bir şekilde anlaşılabilmesi amaciyla 14 (on dört) adet betonarme kısa kiriş numuneleri üç noktadan eksenel eğilme testine tabi tutulmuştur. Deneysel çalışmada eksenel eğilme yükü monotonik olarak betonarme kiriş numunesi göçme moduna ulaşıncaya kadar devam ettirilmiştir. Kısa açıklıklı kirişlerde yük taşıma kapasitesinin büyük bir bölümünün, eğilme çatlaklarının oluşmasından sonra özellikle diyagonal doğrultudaki basınç çubukları tarafından iletilen yüke bağlı olmasından ve oluşan kısmi eğilme çatlaklarından sonra kısa açıklıklı kirişlerin kendi eğilme kapasitelerine ulaşmadan kesme davranışından dolayı gevrek bir şekilde göçmesi nedeniyle, yürütülen deneysel çalışmadan elde edilen verilerin en sağlıklı değerlendirilmesi, karşılaştırma ve sağlama yapılarak doğrulanabilmiştir. Bunun için de deneysel numuneler, her bir grupta 1 (bir) adet katkısız numune olmak üzere üçerli bir set olacak şekilde 5 (beş) gruba ayrılmıştır. Her bir gruptaki deneysel veriler ölçülen yük-deplasman ilişkisine ve göçme modu için yapılan gözlemlere göre değerlendirilmiştir.

\subsection{Grup $B_{1}, B_{7}$ ve $B_{11}$}

$\mathrm{Bu}$ grupta $\mathrm{B}_{1}$ ve $\mathrm{B}_{7}$ numuneleri katkısız olup, $\mathrm{B}_{11}$ numunesinde ise çelik fiber katk1 maddesi kullanılmıştır. $B_{1}$ numunesinde herhangi bir ilave etriye malzemesi uygulamas1 yapilmazken, $\mathrm{B}_{7}$ numunesinde ise ilave etriye malzemesi olarak geogrid uygulaması yapılarak, katkısız numuneler arasında da bir farklılık oluşturulmuştur. Katk1lı olan $\mathrm{B}_{11}$ numunesinde de herhangi bir ilave etriye uygulaması yapılmamıştır. Katkısız olan numunelerde ask1 donatıs1 kullanılmazken, katk11 numunede 0.0033 ask1 donatısı oranı uygulaması yapılmıştır. $B_{1}$ ve $B_{11}$ numunelerinde benzer 0.0033 çekme ve basınç donatısı oranı uygulanırken, $\mathrm{B}_{7}$ numunesinde ise artırılan 0.0035 çekme ve basınç donatısı oranı kullanılarak katkısız numuneler arasında bir başka farklılık daha oluşturulmuştur. Katkısız numunelerdeki bir başka farklılık ise uygulanan etriye aralığı ve elde edilen beton basınç dayanımı parametreleri ile sağlanmıştır. $B_{1}$ katkısız numunesindeki etriye aralığı 400 mm olarak uygulanırken $B_{7}$ katkısız ve $B_{11}$ katkılı numunelerinde ise tartışmanın karşılaştırılabilir olabilmesi amacıyla benzer $150 \mathrm{~mm}$ olarak uygulanmıştır. $\mathrm{B}_{1}$ katkısız ve $B_{11}$ katkılı numunelerde daha yüksek beton basınç seviyeleri ele alınırken, $\mathrm{B}_{7}$ katkısız numunesinde ise buna göre daha düşük beton basınç seviyesi ele alınmıştır. İlk grup için göçme moduna kadar yürütülen eksenel eğilme testi sonuçları Şekil 2'de özetlenmiştir.

$\mathrm{B}_{1}$ katkısız numune hiçbir şekilde eğilme kapasitesine ulaşamadan, kesme ve mesnet bölgesinde aşırı basınç kırılmasından dolayı oldukça gevrek bir davranış gösterirken, $\mathrm{B}_{7}$ katk1s1z ve $\mathrm{B}_{11}$ katk1lı numunelerde ise iletilen yük seviyesine bağlı olarak meydana gelen eğilme çatlaklarından dolayı daha 
sünek bir davranış sergilenmiştir. $\mathrm{B}_{11}$ katkılı numunenin $\mathrm{B}_{7}$ katkısız numuneden ayrılan bir farklılı̆̆ katkılı numunede belirgin bir basınç kırılmasının gerçekleşmemesidir. $\mathrm{B}_{1}$ katkısız numunesine göre $\mathrm{B}_{7}$ katkısız ve $\mathrm{B}_{11}$ katkılı numunelerin ölçülen talep yükü açısından karşılaştırılmasından, $\mathrm{B}_{7}$ katkısız numunede $\% 20$ oranında artan yer değiştirme seviyesinde $\% 14$ oranında bir azalma kaydedilirken, $\mathrm{B}_{11}$ katk1lı numunede ise \% 68 oranında artan yer değiştirme seviyesinde $\% 13$ oranında bir artış hesap edilmiştir. $\mathrm{B}_{7}$ katk1sız ve $B_{11}$ katk1lı numunelerde azalt1lan etriye aralığı sayesinde elde edilen sü- nek davranıştan dolayı beklenti doğrultusunda rijitlikler de azalmıştır. Azalan rijitlikler, $B_{1}$ katkısız numunesine göre $B_{7}$ katkısız ve $B_{11}$ katkılı numunelerde sirasıyla $\% 35$ ve $\% 33$ oranında hesap edilmiştir. $\mathrm{B}_{7}$ katk1sız numunesine göre $\mathrm{B}_{11}$ katk1lı numunedeki artan süneklik oranı ise \% 11 oranında hesap edilmiştir. Ayrıca $\mathrm{B}_{1}$ katkıs1z numunesine göre $B_{7}$ katkısız ve $B_{11}$ katkılı numunelerin artırılan enerji yutma kapasitesi de sirasıyla \% 36 ve \% 122 oranında hesap edilmiştir. Bu grup için ölçülen ve/veya hesap edilen bulgular Tablo 2'de özetlenmiştir.

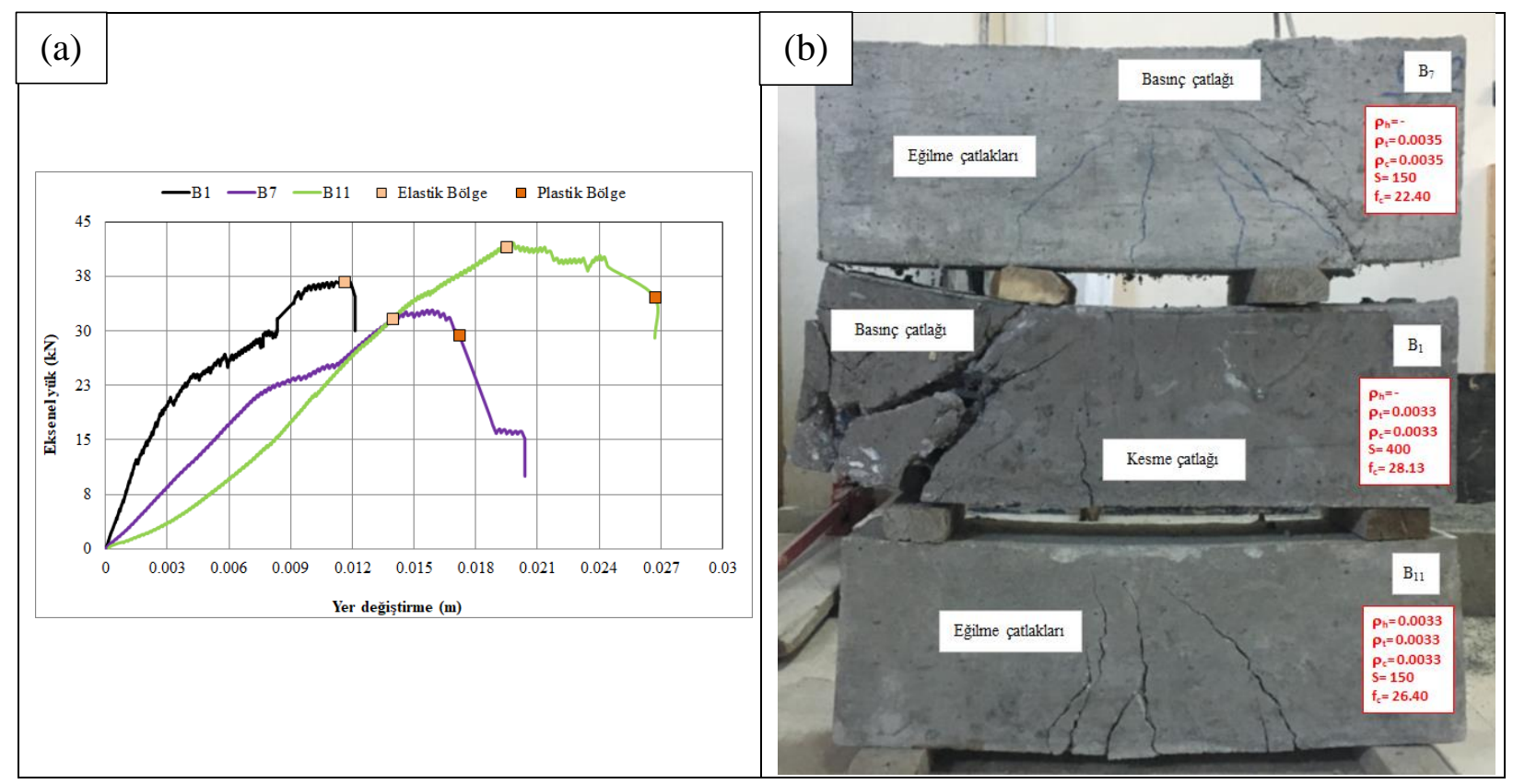

Şekil 2. Grup $\mathrm{B}_{1}, \mathrm{~B}_{7}$ ve $\mathrm{B}_{11}$ eğilme testi sonucu: (a) yük-deplasman ilişkisi; (b) göçme modu.

\subsection{Grup $B_{2}, B_{4}$ ve $B_{10}$}

$\mathrm{Bu}$ grupta $\mathrm{B}_{2}$ ve $\mathrm{B}_{4}$ numuneleri katkısız olup, $\mathrm{B}_{10}$ numunesinde ise paket lastik katkı maddesi kullanılmıştır. Katkısız ve/veya katk1lı numunelerin hiç birisinde herhangi bir ilave etriye malzemesi uygulaması yapılmamıştır. $B_{4}$ katkısız olan numunede askı donatısı kullanılmazken, $\mathrm{B}_{2}$ katkısız ve $B_{10}$ katkılı numunelerde sirasiyla 0.0033 ve 0.0015 ask1 donat1s1 oran1 uygulamas1 yapılmıştır. $B_{4}$ katkısız olan numunede benzer 0.0033 çekme ve basınç donatısı oranı uygulanırken, $B_{2}$ katkısız ve $B_{10}$ katkılı numunelerde ise değişen sırasıyla 0.0033 ve 0.0015 çekme ve basınç donatısı oranı kullanılarak katkısız numuneler arasında başka bir farklılık oluşturulmuştur. Katkısız numunelerdeki bir başka farklılık 
ise uygulanan etriye aralığ 1 ve elde edilen beton basınç dayanımı parametreleri ile sağlanmıştır. $B_{2}$ katkısız numunesindeki etriye aralığ $230 \mathrm{~mm}$ olarak uygulanırken $\mathrm{B}_{4}$ katk1s1z ve $\mathrm{B}_{10}$ katkılı numunelerinde ise tartışmanın karşılaştırılabilir olabilmesi amaciyla sirasiyla 140 ve $150 \mathrm{~mm}$ olarak uygulanmıştır. $\mathrm{B}_{4}$ katkısız ve $\mathrm{B}_{10}$ katkılı numunelerde daha yüksek beton basınç seviyeleri ele alınırken, $\mathrm{B}_{2}$ katkısız numunesinde ise buna göre daha düşük beton basınç seviyesi ele alınmıştır. İkinci grup için göçme moduna kadar yürütülen eksenel eğilme deneyinin sonuçları Şekil 3'de özetlenmiştir.

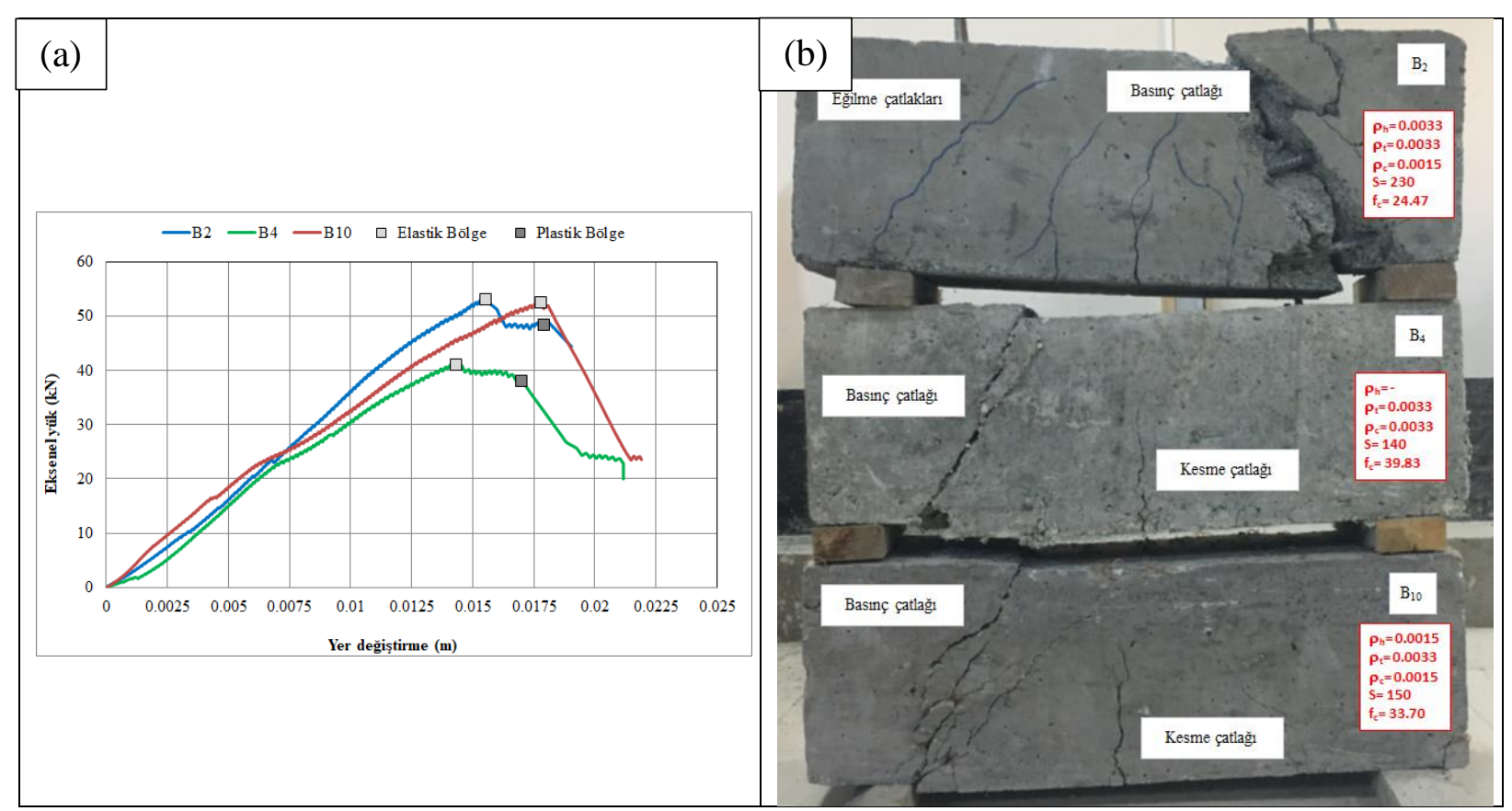

Şekil 3. Grup $\mathrm{B}_{2}$, $\mathrm{B}_{4}$ ve $\mathrm{B}_{10}$ eğilme testi sonucu: (a) yük-deplasman ilişkisi; (b) göçme modu.

$\mathrm{B}_{4}$ katkısız ve $\mathrm{B}_{10}$ katkılı numuneler hiçbir şekilde eğilme kapasitesine ulaşamadan, kesme ve mesnet bölgesinde basınç kırılmasından dolayı gevrek bir davranış gösterirken, $B_{2}$ katkısız numunesi de iletilen yük seviyesine bağlı olarak eğilme çatlakları meydana gelmesine ve kesme davranışının oluşmamasına rağmen, mesnet bölgesinde basınç kırılmasından dolayı gevrek davranış sergilemiştir. $\mathrm{B}_{2}$ katkısız numunenin $\mathrm{B}_{4}$ katk1lı ve $\mathrm{B}_{10}$ katk1s1z numunelerden ayrılan bir farklılığı, askı donatısının kullanılmasına bağlı olarak eğilme çatlaklarının meydana gelmesidir. $\mathrm{B}_{2}$ katkısız numunesine göre $\mathrm{B}_{4}$ katk1sız ve $\mathrm{B}_{10}$ katkılı numunelerin ölçülen talep yükü açısından karşılaştırılmasından, $\mathrm{B}_{4}$ katkısız numunede \%
8 oranında azalan yer değiştirme seviyesinde \% 23 oranında bir azalma kaydedilirken, $\mathrm{B}_{10}$ katk1lı numunede ise \% 15 oranında artan yer değiştirme seviyesinde $\% 1$ oranında bir azalma hesap edilmiştir. $\mathrm{B}_{4}$ katk1sız ve $\mathrm{B}_{10}$ katk1lı numunelerde azaltılan etriye aralığına rağmen, elde edilen gevrek davranıştan dolayı beklentinin aksine rijitlikler de azalmıştır. Azalan rijitlikler, $B_{2}$ katkısız numunesine göre $B_{4}$ katkısız ve $\mathrm{B}_{10}$ katkılı numunelerde sirasıyla \% 16 ve \% 14 oranında hesap edilmiştir. $\mathrm{B}_{2}$ katkısız numunesine göre $\mathrm{B}_{4}$ katkısız numunedeki artan süneklik oranı ise yalnızca \% 3 oranında hesap edilmiştir. Ayrıca $B_{2}$ katkısız numunesine göre $B_{4}$ katkısız ve $B_{10}$ katkı1ı numunelerin değişen enerji 
yutma kapasitesi de sirasiyla \% 11 oranında bir azalma ve \% 13 oranında bir artış hesap edilmiştir. $\mathrm{Bu}$ grup için ölçülen ve/veya hesap edilen bulgular Tablo 2'de özetlenmiştir.

\subsection{Grup B3, B12 ve B14}

$\mathrm{Bu}$ grupta $\mathrm{B}_{3}$ numunesi katk1s1z olup, $\mathrm{B}_{12}$ ve $\mathrm{B}_{14}$ numunesinde ise sirasiyla beton fiber ve sentetik geogrid katk1 maddeleri kullanılmıştır. Katkısız ve/veya katkılı numunelerin hiç birisinde herhangi bir ilave etriye malzemesi uygulaması yapılmamıştır. Katkılı olan numunelerde askı donatısı kullanılmazken, katkısız numunede 0.0033 ask1 donatıs1 oran1 uygulamas1 yapılmıştır. $B_{3}$ katkısız ve $B_{14}$ katkılı numunelerde benzer 0.0033 çekme ve basınç donatısı oranı uygulanırken, $\mathrm{B}_{12}$ katk1lı numunesinde ise artırılan 0.0035 çekme ve basınç donatısı oranı kullanılarak katkılı numuneler arasında bir farkl11ık oluşturulmuştur. $\mathrm{B}_{3}$ katkısız numunesindeki etriye aralığ $200 \mathrm{~mm}$ olarak uygulanırken $B_{12}$ ve $B_{14}$ katk1lı numunelerinde ise tartışmanın karşılaştırılabilir olabilmesi amaciyla sirasiyla 150 ve $140 \mathrm{~mm}$ olarak uygulanmıştır. $\mathrm{B}_{3}$ katkısız numunede daha yüksek beton basınç seviyeleri ele alınırken, $B_{12}$ ve $B_{14}$ katkısiz numunelerde ise buna göre daha düşük beton basınç seviyesi ele alınmıştır. Üçüncü grup için göçme moduna kadar yürütülen eksenel eğilme testi sonuçları Şekil 4' de özetlenmiştir.

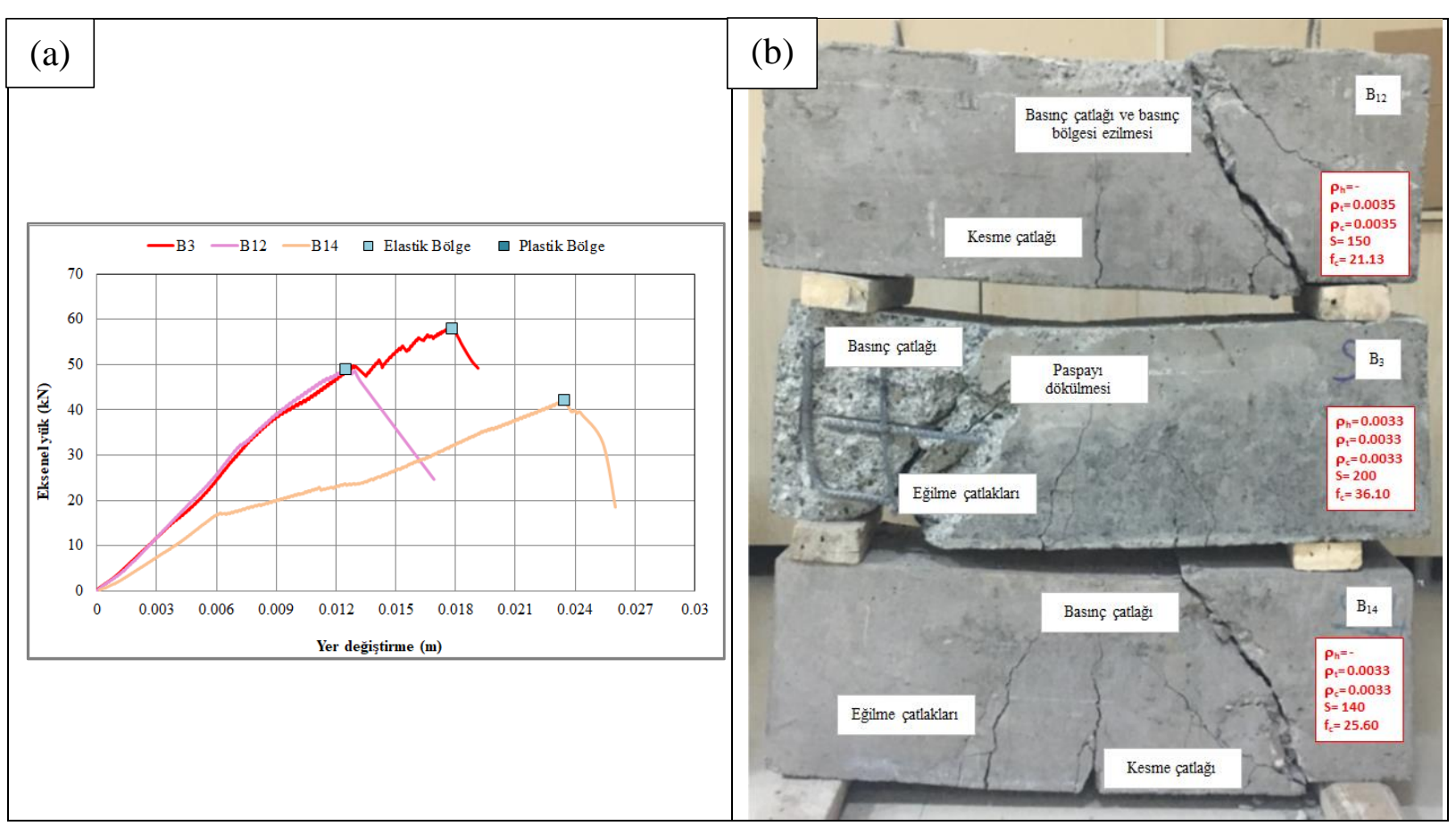

Şekil 4. Grup $B_{3}$, $B_{12}$ ve $B_{14}$ eğilme testi sonucu: (a) yük-deplasman ilişkisi; (b) göçme modu.

Her ne kadar $\mathrm{B}_{3}$ katk1s1z ve $\mathrm{B}_{14}$ katk1lı numunelerde kısmi eğilme çatlakları ortaya çıkmış ve $B_{3}$ katkısız numunede kesme çatlağı oluşmamış olsa da, $B_{3}$ katkısız ile $B_{12}$ ve $B_{14}$ katkılı numuneler hiçbir şekilde eğilme kapasitelerine ulaşamadan, kesme ve mesnet bölgesinde basınç kırılmasından dolayı gevrek davranış sergilemiştir. $\mathrm{B}_{12}$ ve $\mathrm{B}_{14}$ katkılı numunelerin yapısal davranışı için ne beton fiberler ve ne de sentetik 
geogrid katkı maddeleri avantaj sağlamıştır. $\mathrm{B}_{3}$ katkısız numunesine göre $\mathrm{B}_{12}$ ve $\mathrm{B}_{14}$ katkılı numunelerin deneysel ölçülen talep yükü açısından karşılaştırılmasından, $B_{12}$ katkılı numunede $\% 30$ oranında azalan yer değiştirme seviyesinde \% 16 oranında bir azalma kaydedilirken, diğer $\mathrm{B}_{14}$ katk11 numunede ise \% 32 oranında artan yer değiştirme seviyesinde \% 27 oranında bir düşüş hesap edilmiştir. $\mathrm{B}_{12}$ ve $\mathrm{B}_{14}$ katk1lı numunelerde etriye aralığı azaltılmasına rağmen sünek bir davranış elde edilememiştir. Dolayısıyla yer değiştirme sünekliği hesap edilememiştir. Ayrıca katkılı numuneler için rijitlikler de tartış1labilir olarak hesaplanamamıştır. Değişken rijitlikler, $\mathrm{B}_{3}$ katk1sız numunesine göre $B_{12}$ ve $B_{14}$ katk1lı numunelerde sirasıyla \% 20 oranında bir artış ve \% 45 oranında bir düşüş şeklinde hesap edilmiştir. $B_{3}$ katkısız numunesine göre $B_{12}$ ve $B_{14}$ katkılı numunelerin azalan enerji yutma kapasitesi sirasıyla \% 26 ve $\% 17$ oranında hesap edilmiştir. Bu grup için ölçülen ve/veya hesap edilen bulgular Tablo 2'de özetlenmiştir.

\subsection{Grup $B_{5}, B_{6}$ ve $B_{13}$}

$\mathrm{Bu}$ grupta $\mathrm{B}_{5}$ ve $\mathrm{B}_{6}$ numuneleri katk1sız olup, $\mathrm{B}_{13}$ numunesinde ise XPS köpük katkı maddesi kullanılmıştır. Katkısız ve/veya katkılı numunelerin hiç birisinde herhangi bir ilave etriye malzemesi uygulaması yapılmamıştır. Katkısız ve/veya katkılı numunelerin hiç birisinde askı donatısı uygulaması kullanılmamıştır. $B_{5}$ katkısız ve $B_{13}$ katkılı numunelerde benzer 0.0033 çekme ve basınç donatısı oranı uygulanırken, $\mathrm{B}_{6}$ numunesinde ise artırılan 0.0035 çekme ve basınç donatısı oranı kullanılarak katkısız numuneler arasında bir farklılık oluşturulmuştur. Katkısız numunelerdeki bir başka farklılık ise uygulanan etriye aralığı ile sağlanmıştır. $B_{5}$ katkısız ve $B_{13}$ katkılı numunesindeki etriye aralığı sırası ile 130 ve 140 mm olarak uygulanırken $B_{6}$ katkısız numunede ise tartışmanın karşılaştırılabilir olabilmesi amaciyla $220 \mathrm{~mm}$ olarak uygulanmıştır. Katkısız ve/veya katkılı numunelerin tümünde yüksek beton basınç seviyesi ele alınmıştır. Dördüncü grup için göçme moduna kadar yürütülen eksenel eğilme testi sonuçları Şekil 5'de özetlenmiştir.

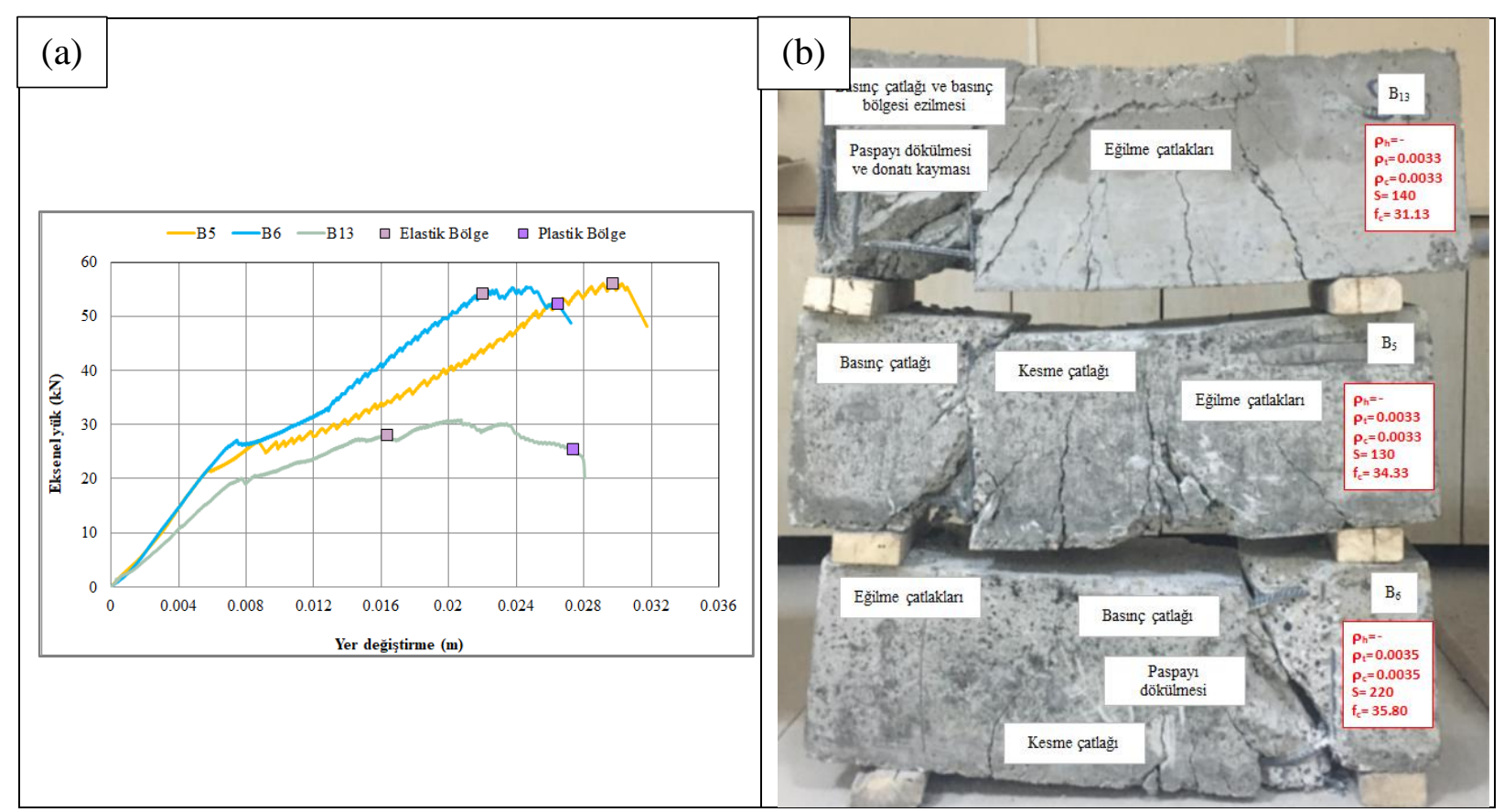

Şekil 5. Grup $\mathrm{B}_{5}, \mathrm{~B}_{6}$ ve $\mathrm{B}_{13}$ eğilme testi sonucu: (a) yük-deplasman ilişkisi; (b) göçme modu. 
$\mathrm{B}_{5}$ ve $\mathrm{B}_{6}$ katkısız numuneler, başlangıçta oluşan eğilme çatlaklarına rağmen, hiçbir şekilde eğilme kapasitesine ulaşamadan, kesme ve mesnet bölgesinde aşırı basınç kırılmasından dolayı gevrek bir davranış gösterirken, $\mathrm{B}_{13}$ katkısız numunesinde ise iletilen yük seviyesine bağlı olarak meydana gelen eğilme çatlakları ve ortaya çıkmayan kesme çatlaklarından dolayı nispeten daha sünek bir davranış sergilenmiştir. Katkı1ı ve katkısız numunelerin tümü için göçme modunda basınç kırılması gerçekleşmiştir. $\mathrm{B}_{5}$ katkısız numunesine göre $\mathrm{B}_{6}$ katkısız ve $\mathrm{B}_{13}$ katkılı numunelerin ölçülen talep yükü açısından karşılaştırılmasından, $\mathrm{B}_{6}$ katkısız numunede $\% 26$ oranında azalan yer değiştirme seviyesinde \% 3 oranında bir azalma kaydedilirken, $\mathrm{B}_{13}$ katk11 numunede ise $\% 45$ oranında daha da artan yer değiştirme seviyesinde \% 50 oranında bir azalma hesap edilmiştir. $\mathrm{B}_{5}$ katkısız ve $\mathrm{B}_{13}$ katkıl1 numunelerde azaltılan etriye aralığı sayesinde genel anlamda elde edilen sünek davranıştan dolayı beklenti doğrultusunda rijitlikler de azalmıştır. Bu anlayışa göre artan ve azalan rijitlikler, $\mathrm{B}_{5}$ katkısız numunesine göre $\mathrm{B}_{6}$ katkısız ve $\mathrm{B}_{13}$ katk1lı numunelerde sirasıyla \% 31 ve $\% 9$ oranında hesap edilmiştir. $B_{6}$ katkısız numunesi- ne göre $\mathrm{B}_{13}$ katk1lı numunedeki artan süneklik oranı ise \% 40 oranında hesap edilmiştir. Ayrıca $\mathrm{B}_{5}$ katkısız numunesine göre $\mathrm{B}_{6}$ katkısız ve $\mathrm{B}_{13}$ katkılı numunelerde belirtilen tasarım gerekçeleri sonucunda azaltılan enerji yutma kapasitesi de sırasıyla \% 12 ve \% 42 oranında hesap edilmiştir. $\mathrm{Bu}$ grup için ölçülen ve/veya hesap edilen bulgular Tablo 2'de özetlenmiştir.

\subsection{Grup B8 ve B9}

$\mathrm{Bu}$ grupta poli-propilen ve cam fiber katk1 maddeleri kullanılan $\mathrm{B}_{8}$ ve $\mathrm{B}_{9}$ numuneleri yer almaktadır. Her iki katkılı numunelerde de ilave etriye malzemesi uygulaması yapılmamıştır. Aynı şekilde her iki katkılı numunelerde de ask1 donatısı kullanılmamıştır. Yine her iki katkılı numunelerde de benzer 0.0033 çekme ve basınç donatısı oranı uygulanmıştır. Katkılı numunelerde birbirlerine yakın beton basınç dayanım seviyesi elde edilirken, tek farklılık uygulanan etriye aralığı ile sağlanmıştır. $B_{8}$ ve $\mathrm{B}_{9}$ katkılı numunelerdeki etriye aralıkları sirasıyla 130 ve $100 \mathrm{~mm}$ olarak uygulanmıştır. Son grup için göçme moduna kadar yürütülen eksenel eğilme testi sonuçları Şekil 6' da özetlenmiştir.

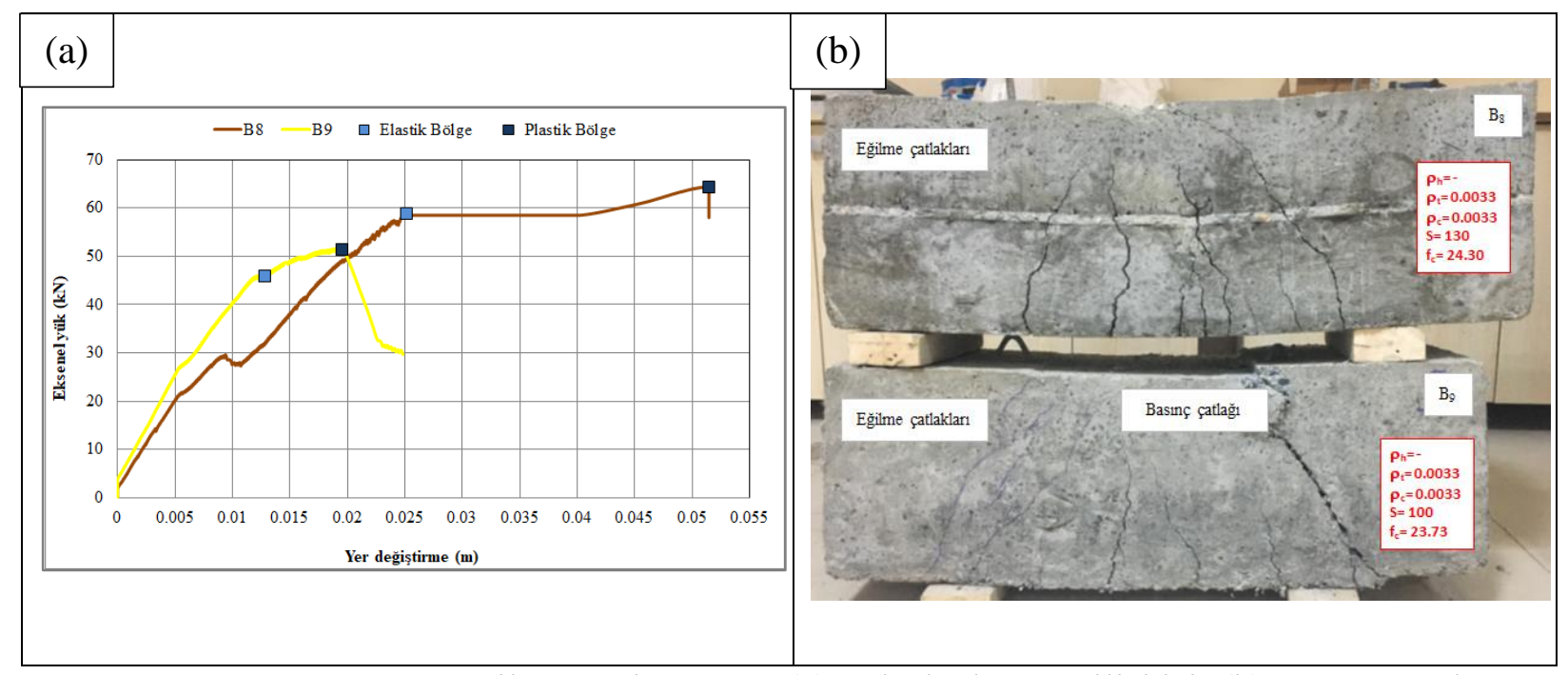

Şekil 6. Grup $\mathrm{B}_{8}$ ve $\mathrm{B}_{9}$ eğilme testi sonucu: (a) yük-deplasman ilişkisi; (b) göçme modu. 
Her iki $\mathrm{B}_{8}$ ve $\mathrm{B}_{9}$ katkılı numunelerde iletilen yük seviyesine bağlı olarak meydana gelen eğilme çatlaklarından dolayı sünek davranış sergilenmiştir. $\mathrm{B}_{8}$ katkılı numunesinin $\mathrm{B}_{9}$ katk1lı numunesinden ayrilan bir farklılığı, mekanik çekme ve iletilen yükler arasında köprüleme gibi ana özelliklere sahip poli-propilen fiber sayesinde belirgin bir basınç kırılmasının gerçekleşmemesidir. $\mathrm{B}_{8}$ katk111 numunesine göre $\mathrm{B}_{9}$ katk11 numunesinin ölçülen talep yükü açısından karşılaştırılmasından, \% 49 oranında azalan yer değiştirme seviyesinde \% 22 oranında bir azalma hesap edilmiştir. B9 katk111 numunede etriye aralıkları azaltılmasina rağmen, $\mathrm{B}_{8}$ numunesindeki kadar süneklik elde edilememiştir. Dolayısıyla B9 katkılı numunede beklenti doğrultusunda rijitlik de artmıştır. Artan rijitlik seviyesi, $\mathrm{B}_{8}$ katkılı numunesine göre \% 54 oranında hesap edilmiştir. $\mathrm{B}_{8}$ katkılı numunesine göre $\mathrm{B}_{9}$ katkılı numunedeki azalan yer değiştirme süneklik oranı ise \% 25 oranında hesap edilmiştir. Ayrıca $\mathrm{B}_{8}$ katkılı numunesine göre $\mathrm{B}_{9}$ katk1lı numunenin azalan enerji yutma kapasitesi de \% 63 ve oranında hesap edilmiştir. Son grup için de ölçülen ve/veya hesap edilen bulgular Tablo 2'de özetlenmiştir.

Tablo 2 Ölçülen ve/veya hesap edilen deneysel bulgular

\begin{tabular}{|c|c|c|c|c|c|c|c|c|c|c|}
\hline \multirow{2}{*}{ 音 } & \multicolumn{2}{|c|}{ Elastik Bölge } & \multicolumn{2}{|c|}{ Plastik Bölge } & \multirow{2}{*}{$\begin{array}{l}\text { Rijitlik } \\
(\mathbf{k N} / \mathbf{m})\end{array}$} & \multirow{2}{*}{$\begin{array}{l}\text { Süneklik } \\
(\mathbf{m} / \mathbf{m})\end{array}$} & \multirow{2}{*}{$\begin{array}{l}\text { Enerji } \\
\text { (Joule) }\end{array}$} & \multirow{2}{*}{$\begin{array}{c}\text { Etriye } \\
\text { aralığı } \\
(\mathbf{m m})\end{array}$} & \multirow{2}{*}{$\begin{array}{c}\mathbf{f}_{\mathrm{c}} \\
(\mathbf{M p a})\end{array}$} & \multirow{2}{*}{ Göçme modu } \\
\hline & Yük & Dep. & Yük & Dep. & & & & & & \\
\hline $\mathbf{B}_{1}$ & 36.82 & 0.0116 & - & - & 3173.9 & - & 303.1 & 400 & 28.13 & Gevrek, eğilme yok, kesme var, basınç kırılması \\
\hline $\mathbf{B}_{2}$ & 53.18 & 0.0155 & 48.54 & 0.0179 & 3432.9 & 1.15 & 589.8 & 230 & 24.47 & Gevrek, eğilme var, kesme yok, basınç kırılması \\
\hline $\mathbf{B}_{3}$ & 58.07 & 0.0178 & - & - & 3268.8 & - & 668.2 & 200 & 36.10 & $\begin{array}{l}\text { Gevrek, eğilme var, kesme yok, basınç kırılması, } \\
\text { pas payı dökülmesi }\end{array}$ \\
\hline $\mathbf{B}_{4}$ & 41.21 & 0.0143 & 38.11 & 0.0170 & 2882.3 & 1.19 & 526.6 & 140 & 39.83 & Gevrek, eğilme yok, kesme var, basınç kırılması \\
\hline $\mathbf{B}_{5}$ & 56.16 & 0.0297 & - & - & 1891.2 & - & 1069.9 & 130 & 34.33 & Gevrek, eğilme var, kesme var, basınç kırılması \\
\hline $\mathbf{B}_{6}$ & 54.33 & 0.0219 & 52.39 & 0.0264 & 2475.8 & 1.20 & 942.1 & 220 & 35.80 & $\begin{array}{l}\text { Gevrek, eğilme var, kesme var, basınç kırılması, } \\
\text { pas payı dökülmesi }\end{array}$ \\
\hline $\mathbf{B}_{7}$ & 31.74 & 0.0140 & 29.45 & 0.0172 & 2272.6 & 1.23 & 411.7 & 150 & 22.40 & Sünek, eğilme var, kesme yok, basınç kırılması \\
\hline $\mathbf{B}_{8}$ & 58.97 & 0.0251 & 64.34 & 0.0514 & 2347.7 & 2.05 & 2414.0 & 130 & 24.30 & $\begin{array}{l}\text { Sünek, eğilme var, kesme yok, basınç kırılması } \\
\text { yok }\end{array}$ \\
\hline B9 & 46.05 & 0.0128 & 51.40 & 0.0195 & 3611.0 & 1.53 & 893.1 & 100 & 23.73 & Sünek, eğilme var, kesme yok, basınç kırılması \\
\hline $\mathbf{B}_{10}$ & 52.58 & 0.0178 & - & - & 2961.9 & - & 668.6 & 220 & 33.70 & Gevrek, eğilme yok, kesme var, basınç kırılması \\
\hline $\mathbf{B}_{11}$ & 41.61 & 0.0195 & 34.64 & 0.0267 & 2135.1 & 1.37 & 674.2 & 150 & 26.40 & $\begin{array}{l}\text { Sünek, eğilme var, kesme yok, basınç kırılması } \\
\text { yok }\end{array}$ \\
\hline $\mathbf{B}_{12}$ & 49.01 & 0.0124 & - & - & 3937.4 & - & 492.1 & 150 & 21.13 & Gevrek, eğilme yok, kesme var, basınç kırılması \\
\hline $\mathbf{B}_{13}$ & 28.10 & 0.0163 & 25.58 & 0.0274 & 1725.0 & 1.68 & 617.4 & 140 & 31.13 & $\begin{array}{l}\text { Sünek, eğilme var, kesme yok, basınç kırılması, } \\
\text { donatı kayması }\end{array}$ \\
\hline $\mathbf{B}_{14}$ & 42.26 & 0.0234 & - & - & 1802.7 & - & 620.3 & 140 & 25.60 & Gevrek, eğilme var, kesme var, basınç kırılması \\
\hline
\end{tabular}

\section{Sonuç}

$\mathrm{Bu}$ çalışmada farklı katkı maddelerinin (örneğin, poli-propilen fiber, cam elyaflar, paket lastikler, çelik/beton fiberler, ..., gibi) betonarme kısa açıklıklı kirişlerin kesme kapasitesi üzerindeki performansını incelemek amacıyla bir dizi deneysel çalışma yürütülmüştür. Toplam 14 (on dört) adet deneysel betonarme kısa-açıklıklı kiriş numuneleri, üç noktadan eksenel eğilme testine tabi tutulmuştur. Monotonik yükleme sistemi ile eş-zamanlı ölçülen yükdeplasman ilişkisine bağlı olarak, yapısal 
davranış ve göçme modları, yük taşıma kapasitesi, katkı maddesi türü, askı/çekme ve basınç bölgesi donatı oranı ile beton basınç dayanımı parametrelerine bağlı olarak tartışılmıştır. Farklı katkı maddelerine ve farklı beton dayanım seviyelerine sahip kısa-açıklıklı kirişler üzerinde yürütülen deneysel verilerden aşağıdaki sonuçlar elde edilmiştir.

Elastik bölgede yük taşıma kapasitesi ve deplasman yapabilme yeteneği açısından en avantajlı katk1 maddesi sirasiyla kendisine en yakın paket lastik katkı maddesine göre ortalama \% 11 oranında ve sentetik geogrid katk1 maddesine göre ortalama \% 7 oranında bir fark oluşturan poli-propilen fiber katkı maddesi olmuştur. Plastik bölgede de aynı şekilde yük taşıma kapasitesi ve deplasman yapabilme yeteneği açısından en avantajlı katkı maddesi sirasıyla kendisine en yakın cam fiber katkı maddesine göre ortalama \% 20 oranında ve XPS köpük katkı maddesine göre ortalama \% 47 oranında bir fark oluşturan poli-propilen fiber katkı maddesi olmuştur. Ayrıca süneklik ve enerji yutma kapasitesi gibi yap1sal parametreler dikkate alındığında, polipropilen fiber katkı maddesi sirasıyla kendisine en yakın XPS köpük katkı maddesine göre ortalama \% 18 oranında ve cam fiber katkı maddesine göre ortalama \% 63 oranında bir yapısal artış sağlamaktadır.

Betonarme kiriş numunelerinde ask1 donatısı uygulamasının her iki katkısız ve katk111 kiriş numunelerinin yapısal davranışlarında bir kararsızlık oluşturduğu anlaşı1maktadır. Öyle ki katkısız ve katkılı numunelerde ask1 donatısı oranının artırılması elastik bölgede yük taşıma kapasitesinde sırasıyla ortalama \%10 oranında bir artış ve $\% 21$ oranında bir azalmaya neden olurken, deplasman yapabilme yeteneğinde ise ortalama \% 13 oranında bir azalma ve \% 10 oranında bir artış sağlanabilmiştir. Dengeli donatı oranı uygulamasının yapı davranışı için yeterli olduğu gerçeğinden dolay1, çekme ve/veya basınç donatısı oranının artırılması katkısız ve katkılı numunelerde rijitlik hariç olmak üzere tüm elastik ve plastik bölgedeki yük taşıma kapasitesi ve deplasman yapabilme yeteneği ile süneklik ve enerji yutma kapasitesi yapısal davranış parametrelerinde azalmalara neden olmuştur. Deneysel çalışma sayesinde kısa açıklıklı kirişlerde etriye aralığının azaltılması ile yapı talep yükü ile rijitliğin azaltılarak, süneklik ve enerji yutma kapasitesinin art1rılması konusu da doğrulanmıştır.

\section{Kaynaklar}

American Concrete Institute (ACI), (2011). "ACI 318-14: Building Code Requirements for Structural Concrete," Farmington Hills, MI.

ASTM C 39-01, (2001). "Standard test method for compressive strength of cylindrical concrete specimens", Annual book of ASTM standards, Philadelphia: American Society for Testing and Materials.

Bicer, K., Yalciner, H., Balkıs, A. B. and Kumbasaroglu, A., (2018). "Effect of corrosion on flexural strength Of reinforced concrete beams with polypropylene fibers," Journal of Construction and Building Materials, 185, pp. 574-588.

Caglar, N., Demir, A., Ozturk, H., and Akkaya, A. (2015). "A new approach to determine the moment-curvature relationship of circular reinforced concrete columns," Computers and Concrete, 15(3), pp. 321-335.

Campione, G., and Mangiavillano, ML., (2008). "Fibrous reinforced concrete beams in flexure: Experimental investigation, analytical modelling and 
design considerations," Engineering structures, 30(11), pp. 2970-2980.

Demir, A., Caglar, N., Ozturk, H., and Sumer, Y., (2016). "Nonlinear finite element study on the improvement of shear capacity in reinforced concrete T-Section beams by an alternative diagonal shear reinforcement," Engineering Structures, 120, pp. 158-165.

Karami, G., Malekzadeh, P., and Shahpari, SA., (2003). "A DQEM for vibration of shear deformable nonuniform beams with general boundary conditions," Engineering Structures, 25(9), pp. 1169-1178.

Khan, A., Smith, DL., and Izzuddin, BA., (2013). "Investigation of rigid-plastic beams subjected to impact using linear complementarity," Engineering structures, 50, pp. 137-148.

Kumbasaroglu, A., and Korkmaz, M., (2020). "Poli-propilen fiber katkısının betonarme kirişlerde bindirme boyuna etkisi" 4. Uluslararası GAP MatematikMühendislik Fen Ve Sağlı Bilimleri Kongresi, pp. 36-59.

Kuo, WW., Cheng, TJ., and Hwang, SJ., (2010). "Force transfer mechanism and shear strength of reinforced concrete beams," Engineering Structures, 32(6), pp. 1537-1546.

Lele, SP., and Maiti, SK., (2002). "Modelling of transverse vibration of short beams for crack detection and measurement of crack extension," Journal of sound and Vibration, 257(3), pp. 559583.

Syroka-Korol, E., and Tejchman, J., (2014). "Experimental investigations of size effect in reinforced concrete beams failing by shear," Engineering Structures, 58, pp. 63-78.

TS 708, (2010). "Steel for the reinforcement of concrete-Reinforcing steel", Turkish Standard Institution, Ankara.
TS 500, (2002). "Requirements for design and construction of reinforced concrete structures", Turkish Institute of Standards, Ankara.

Yalciner, H., Kumbasaroglu, A., and Ergun, U., (2018). "Effects of geo-grid and conventional stirrups on reinforced concrete beams with polypropylene fibers," Structures, 13, pp. 230-242.

Yazdanbakhsh, A., Altoubat, S., and Rieder, KA., (2015). "Analytical study on shear strength of macro synthetic fiber reinforced concrete beams," Engineering Structures, 100, pp. 622-632.

Yu, Q., and Bažant, ZP., (2011). "Can stirrups suppress size effect on shear strength of RC beams?," Journal of Structural Engineering, 137(5), pp. 607617.

Wight, JK., and Macgregor, JG., (2012). "Reinforced Concrete Mechanics and Design," 6 th, Editi ed., United States of America, (USA). 